\title{
SUSAN CIVALE
}

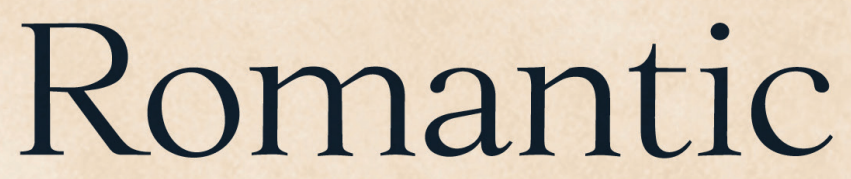

women's life

\section{writing}

Reputation and afterlife

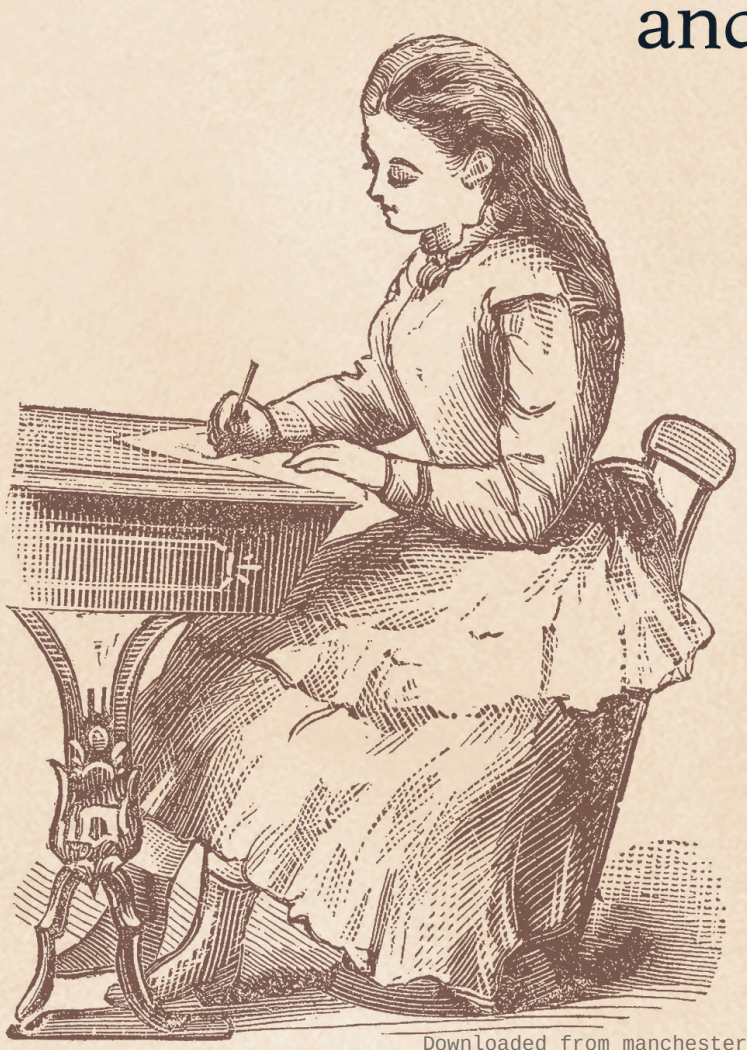


ROMANTIC WOMEN'S LIFE WRITING

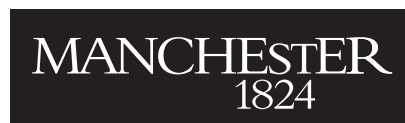

Manchester University Press 
Susan Civale - 9781526101273

Downloaded from manchesterhive.com at 04/26/2023 11:26:24AM 


\title{
Romantic women's life writing
}

\author{
Reputation and afterlife
}

\author{
Susan Civale
}

Manchester University Press 


\title{
Copyright (C) Susan Civale 20 I 9
}

The right of Susan Civale to be identified as the author of this work has been asserted by her in accordance with the Copyright, Designs and Patents Act i 988.

Published by Manchester University Press Altrincham Street, Manchester M I 7 JA www.manchesteruniversitypress.co.uk

\section{British Library Cataloguing-in-Publication Data}

A catalogue record for this book is available from the British Library

ISBN 978 I 526 I 01167 hardback

First published 2019

The publisher has no responsibility for the persistence or accuracy of URLs for any external or third-party internet websites referred to in this book, and does not guarantee that any content on such websites is, or will remain, accurate or appropriate.

\author{
Typeset by \\ Deanta Global Publishing Services
}

